tørene klart å lage en helhetlig presentasjon, både $\mathrm{i}$ form og innhold. Boken består av tre hoveddeler som er bygd opp over samme lest, alle med fyldig referanseliste. Layouten er oversiktlig og tiltalende. Boken er rettet mot helsefagstudenter og helsepersonell, og den vil fungere fint både som lærebok og for de mer erfarne. Bidragsyterne peker også på behovet for videre forskning og kan kanskje stimulere flere til å begynne med det?

I den første delen gir forfatterne en grundig innføring i migrasjon og det flerkulturelle samfunn. Her drøfter de hvilke faktorer som er de viktigste når vi skal forklare faktiske etniske helseforskjeller. Er det graden av kulturell tilpasning, sosioøkonomisk status, genetikk eller effekten av migrasjon i seg selv? Vi får også presentert migrasjonsprosesser, statistikk over innvandring i Norge og helseforhold for ulike grupper. Det siste kapitlet omhandler ulike kulturers syn på helse og sykdom, og hvilke krav dette setter til oss som helsearbeidere. Forfatterne legger her vekt på at kulturell bevissthet og kultursensitivitet kan være mer nyttig enn generell kulturkunnskap.

I den andre delen tar forfatterne tak i aktuelle folkehelseutfordringer med hovedvekt på diabetesepidemien, fysisk aktivitet og kosthold. Andre temaer er smittevern, rett til likeverdig helsetjeneste samt psykisk helse og sosial mestring. Opplevelse av maktesløshet beskrives som den største risikofaktoren for å utvikle psykiske plager. Det kunne gjerne vært nevnt at de samme risikofaktorene også kan ha sammenheng med subjektive helseplager, da dette kanskje er den største utfordringen mange opplever i praksis.

Den siste delen har et livsløpsperspektiv. Her blir det noen gjentakelser fra tidligere, men forfatterne går også mer i dybden og har gode, konkrete eksempler. Når de har valgt å sette søkelyset på selve livsløpet, savner jeg imidlertid bredere omtale av de store hendelsene i livet, som svangerskap, barseltid og død. Dette er sårbare situasjoner hvor vi som helsearbeidere kommer svært tett innpå familier, og hvor kulturell bakgrunn kan ha stor betydning.

Hovedbudskapet er at en god helsetjeneste for minoriteter også er en god helsetjeneste for etniske nordmenn. Ved å møte pasienten med en åpen og respektfull innstilling, være spørrende, «ikke-vitende» og nysgjerrige, kan vi legge grunnlaget for en god dialog. Vi må ikke se oss blinde på ulikhetene, og ikke tro at alle forskjeller skyldes kultur i seg selv. I møtet med den enkelte pasient er det ofte likhetene som binder oss sammen.

Inger Johanna Jervidalo Meltvedt Fjell legesenter Drammen

\section{God EKG-bok for indremedisinere}

Sverker Jern Klinisk EKG-diagnostik

254 s, ill, CD. Ljungskile: Sverker Jern utbildning, 2010. Pris SEK 699

ISBN 978-91-633-6666-6

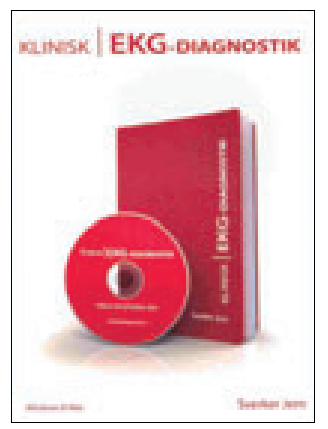

Sverker Jern (f. 1954) er en autoritet på $\mathrm{EKG}$, med lang fartstid ved Sahlgrenska Universitetssjukhuset og med ansvar for den sentraliserte EKGtolkningen i LIFEstudien. I 1984 ga han ut en lærebok

i EKG som raskt fikk stor utbredelse, hovedsakelig i Sverige. Nå har han kommet med en ny, betydelig utvidet utgave.

Boken er tradisjonelt bygd opp med hovedstrukturen introduksjon, arytmier og morfologisk diagnostikk, og underkapitler, som til sammen dekker feltet godt. Det er mye tekst, men også utsøkt gode illustrasjoner i fargetrykk. Registeret er godt. Det er et fåtall skrivefeil og feilformuleringer, og teksten er oppdatert etter de nyeste retningslinjene.

Teksten er akademisk saklig, omfattende og korrekt i sin beskrivelse av hvordan EKG ser ut ved tilstand etter tilstand, men forfatterens sannsynlige begeistring for faget slipper aldri igjennom. For medisinstudenter synes jeg at det er en svakhet at boken vesentlig beskriver, men unnlater å forklare. Den undrende studenten finner ikke svar på hvorfor iskemi transmuralt gir ST-løft, mens det i subendokard vises som ST-senkning. Eller hvorfor T-bølgen normalt blir konkordant med QRS-vektor, mens atriets repolarisering er motsatt rettet P-bølgen. Eller hvorfor s-Ca ${ }^{2+}$ påvirker QTtiden. Dagens fysiologiske kunnskap gir oss mulighet til å kunne forstå mer enn å måtte huske. Denne mangelen deles imidlertid med de fleste andre aktuelle EKG-bøkene på markedet.

Det følger med en CD med EKGeksempler, utarbeidet av datteren Helene Jern. Denne krever oppkobling til Internett for å aktiveres, og skal tillate installasjon på to PCer for hver lisens. Dette fungerte ikke opp mot tjeneren og sikkerhetsprogrammet ved Universitetet i Oslo før utgiverne modifiserte sitt program. Her er eksemplene gode og ordnet etter vanskelighetsgrad (tre nivåer). Brukeren beskriver rytme, overledning og morfologi ved hjelp av elektronisk stikkpasser og rullemenyer, og kan bryne svaret mot en stikkordpreget fasit. Her kunne det med fordel også vært en lenke til mer utdypende kommentarer om det enkelte $\mathrm{EKG}$, både om premissene for diagnosen, ev. alternative tolkninger og litt om klinisk relevans.

Forfatteren har valgt ikke å ta med barneEKG. Så dekkende boken ellers er, kunne det vært naturlig i det minste å vise den normale utviklingen med alderen. Svært mange bruker EKG-apparater med elektronisk tolkningsprogram. Slike programmer har noen sterke sider, men begår ofte grove, karakteristiske feil. Noen eksempler på slike fallgruver kunne også godt vært tatt med. Heller ikke senpotensial-EKG eller analyse av hjertefrekvensvariasjon er omtalt, mens langtids-EKG er meget pedagogisk omtalt.

Samlet vurdert er dette en god bok for utdanningskandidater i indremedisin, interesserte primærleger og studenter. Den passer best for dem som allerede har noe kunnskap om EKG. For leger som utdanner seg i kardiologi, blir det for snaut.

Knut Gjesdal

Hjertemedisinsk avdeling

Oslo universitetssykehus, Ullevål

\section{Spesialisert om generalisering}

Marie T. Banich, Donna Caccamise, red. Generalization of knowledge

Multidisciplinary perspectives. 365 s, tab, ill. Hove: Psychology Press, 2010. Pris GBP 48 ISBN 978-1-84872-898-1

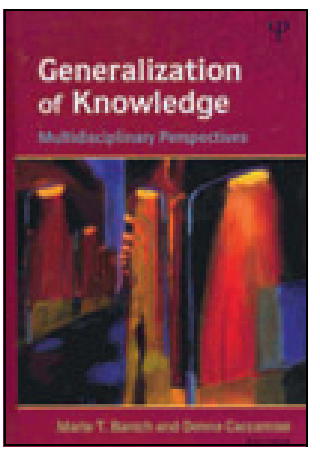

Evne til å generalisere kunnskap er avgjørende for vår evne til å skape mening av verden rundt oss. Uten å forenkle informasjon ved å kategorisere ville verden bare bestå av løsrevne detaljer. Kategorisering gir oss viktig forhåndskunnskap når vi møter nye individer, objekter og situasjoner. Generalisering er også sentralt for vår evne til å identifisere årsakssammenhenger og forutsi fremtidige hendelser basert på erfaringer. Men generalisering er som en mynt med to sider: Baksiden er overforenkling og fordommer.

Denne boken er en samling av 15 artikler basert på et tredagers symposium, hvor målet ikke bare er å presentere oppdatert kunnskap om generalisering fra mange disipliner, men å lete etter «general principles of generalization».

Boken består av fem deler, hver med tre artikler forfattet av ledende forskere innen sine områder. Første del omhandler hvordan 
man studerer generalisering innen kognitiv nevrovitenskap. I kapittel 1 tar forfatterne for seg læring ved betinging. Kapittel 2 omhandler generalisering og ekspertise, bl.a. data som tyder på at økende ekspertise (her studert ved kategorisering av synsinntrykk) faktisk reduserer evnen til å forholde seg til elementer i et sammensatt bilde eksperten baserer seg på en holistisk oppfatning slik at distinkte komponenter i et bilde gradvis behandles som en enhet. Dette kan, f.eks. for en meget erfaren lege, representere en risiko for å overse verdifull informasjon. Et område hvor vi alle oppfyller kriteriene for ekspertise, er ansiktsgjenkjenning. Alle har vel opplevd hvor raskt vi gjenkjenner ansikter - uten anstrengelse eller bevisst analyse - men også ofte uten etterpå å kunne gjengi detaljer som øyefarge, eller til og med om skjegget fortsatt var der. Artikkelen refererer også til studier av i hvilken grad ekspertkunnskap innen et domene er overførbart til et annet. Svaret er selvfølgelig at det kommer an på, men generelt kan man ikke ta overføring for gitt. I medisinsk utdanning har vi f.eks. en tendens til ukritisk å ta for gitt betydelig grad av overføring av generalisert kunnskap. I kapittel 3 tar forfatterne for seg hvordan nevrale systemer for ulike typer av hukommelse kan behandle både spesifikke og generaliserte aspekter av erfaringer. I denne sammenhengen beskriver forfatterne organiseringen av multiple hukommelsessystemer, hvor bl.a. basalgangliene og hippocampus har ulike oppgaver.

I annen del behandler bidragsyterne generalisering i et utviklingsperspektiv. Hvordan utvikles evnen til generalisering hos spedbarnet og i tidlig barnealder? Hvordan lærer spedbarnet en generell regel, ofte basert på overraskende få eksempler? Her omtaler de også hvordan barnet tidlig mister evnen til å høre forskjell på språklyder som ikke brukes til å skille mellom ord (f.eks. ulike uttaler av 1 som gir fonetisk informasjon i noen språk, men ikke i andre). De diskuterer også hvilke faktorer vi baserer oss på når vi generaliserer, f.eks. når vi lærer begrepet hund. Hva er viktigst: Er det rent perseptuelle forhold (form, lukt, lyd, følelse ved å ta på), eller er det mer atferdsmessige forhold som hvordan en hund oppfører seg? Mange av eksemplene i denne og andre deler er tatt fra læring av språk i tidlig barnealder.

I tredje del - Representations that support generalization - bruker forfatterne bl.a. bayesiansk statistikk for å studere mekanismene bak menneskers dyktighet til å generalisere. Videre diskuterer de hvordan generell og spesifikk informasjon er representert mentalt. Det dreier seg om mentale «modeller» av virkeligheten, og hva som karakteriserer dem. Slike modeller er under stadig konstruksjon, er subjektive og underlagt tolkning av tilgjengelig informasjon. Her omtaler de igjen ekspertbegrepet og hva som kjennetegner eksperters generaliseringer. For eksempel diskuterer de undersøkelser av leger som eksperter. Erfarne legers diagnosestilling tenderer til å bli basert på likhet med spesifikke eksempler, mer enn på generelle fellestrekk for alle eksemplene de har sett. Dette medfører en fare for å bli for lite sensitiv for nye eksempler som likner lite på tidligere erfaringer, men som passer med de mer generelle kriteriene for en kategori.

Fjerde del omhandler hvordan generalisering best kan oppnås i utdanningssituasjoner. I kapittel 10 ser forfatterne på databaserte programmer og dataspill for læring av bl.a. språk (f.eks. spillmiljøer hvor eleven kommuniserer med en virtuell veileder gjennom språk eller handlinger). Her diskuterer de igjen faktorer som kan redusere eller øke sannsynligheten for overføring av kunnskap fra løsning av et problem til et annet. Nytteverdien av teknologi for læring diskuteres, og forfatterne fremhever at selv om teknologibaserte læringsmidler til nå ser ut til å ha hatt liten pedagogisk betydning, antas dette å forandre seg raskt når man tar tilstrekkelig hensyn til de kritiske faktorene som avgjør om læring vil foregå $\mathrm{i}$ et møte mellom mennesker og datamaskiner. Kapittel 11 omhandler hvordan tekniske og vitenskapelige begreper blir distribuert og generalisert $i$ en arbeidsgruppe. Her gjengir forfatterne bl.a. en grundig studie av samarbeid $i$ team $i$ klinisk medisin (en gruppe skulle finne beste metode til å bestemme antall hospitaliserte barn med influensa $i$ en bestemt periode). Denne forskningen er rimeligvis relevant for medisinere, som ofte fungerer som formelle eller uformelle teamledere. Hva skal til for at et team fungerer effektivt med hensyn til utvikling og deling av kunnskap?

Siste og femte del omhandler teknologiske tilnærminger til generalisering.

I kapittel 13 tar forfatterne for seg studier av interaksjon mellom mennesker og datamaskiner, spesielt med henblikk på utvikling av programmer for opptrening av afasipasienter. De understreker at for sterk generalisering av grensesnitt skaper problemer hvis det ikke suppleres av betydelig individuell tilpasning, fordi gruppen av afasipasienter er så heterogen. I kapittel 15 drøfter de videre hvordan grensesnitt kan utformes for å være tilstrekkelig spesifikke og fortsatt ha fleksibilitet. Behovet for dette eksemplifiseres ved utvikling av dataprogrammer som skal hjelpe personer med kognitiv svikt til å løse oppgaver de ellers ikke ville greid. Til slutt drøfter de konflikten mellom å gi både bred, generell kunnskap og sterk disiplinspesialisering i dagens utdanningssystem. Denne konflikten er ikke minst aktuell i dagens medisin og i medisinsk utdanning. Én løsning er såkalte «reflective communities» som prøver å oppnå «collective comprehensiveness through overlapping patterns of unique narrowness»».

Den multidisiplinære tilnærmingen viser at generalisering er et komplekst fenomen, og at den presise meningen er sterkt kontekstavhengig. Det er derfor kanskje bare et tilsynelatende paradoks at en bok om generalisering er sterkt spesialisert. Generelle prinsipper for generalisering er ikke så lette å finne. Forfatterne gir likevel interessante bidrag på et høyt faglig nivå, for å belyse en av menneskets mest fundamentale kognitive ferdigheter.

\section{Per Brodal}

Institutt for medisinske basalfag

Universitetet i Oslo

\section{Intensivmedisinske prosedyrer}

Heidi L. Frankel, Bennett P. deBoisblanc, red. Bedside procedures for the intensivist

341 s, tab, ill. Heidelberg: Springer, 2010 Pris EUR 54

ISBN 978-0-387-79829-5

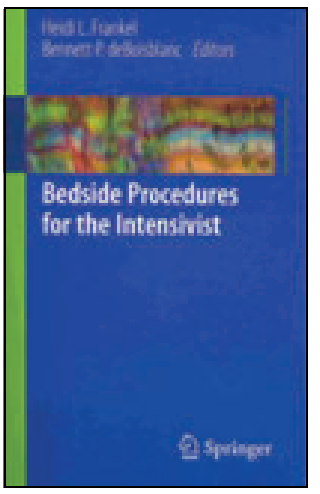

Diagnostikk og behandling av intensivpasienter har hatt en formidabel utvikling siden starten i 1950-årene. I tråd med den teknologiske utviklingen på feltet har også praksis endret seg, og prosedyrer som tidligere ble gjort på røntgenlabora-

toriet eller operasjonsstuen, kan i dag gjøres ved sengen på intensivavdelingen. Dette er en fordel da transport av intensivpasienter er svært ressurskrevende og innebærer risiko for komplikasjoner.

Redaktørene har organisert stoffet i 17 kapitler, hvor forfatterne tar for seg de vanligste prosedyrene på en intensivavdeling med både medisinske og kirurgiske pasienter. Forfatterne retter søkelyset mot ultralydteknikker og gir en innføring i ultralydfysikk og ultralydprinsipper. Hvert kapittel starter med en kort introduksjon, deretter forklarer de teknikken, lister opp indikasjoner og kontraindikasjoner, gjennomgår utstyr og forberedelse til prosedyren og beskriver komplikasjoner under og etter prosedyren. En del kapitler avsluttes med en oppsummering/konklusjon. Etter hvert kapittel er det en referanseliste. Den trinnvise innføringen i hvordan man skal gjennomføre prosedyren, er rikt illustrert med mange fargefotoer og anatomiske skisser.

Med et par unntak er det kun amerikanske forfattere, og praksis vedrørende medikamentbruk kan avvike noe fra norske forhold. Tilsvarende vil ikke apparatur og 